\title{
Farewell
}

Bongani Mayosi was an extraordinary person who touched the lives of all those who had the privilege of meeting him, however fleetingly. Like all those who knew him, I am deeply affected by his untimely death. I cannot add to the substantive commentaries already here. All I can do is add the translation of the poignant isiXhosa words offered by another great, Prof. Ntobeko Ntusi:

'Sleep in peace Rhadebe [his clan name]. Sleep in peace, you who have been the most victorious of victors. That which God sent you here [to do], you accomplished. A good effort you put in. And now you have completed your race.'

Rest well, Bongani. You are sorely missed.

\section{Bridget Farham}

Editor

ugqirha@iafrica.com 